\title{
制御積雪荷重を用いる勾配屋根における制御日数について ON THE TERM CONTROLLED BY SNOW LOAD : PRACTICAL USE OF SNOW SLIDING ON PITCHED ROOF
}

\author{
高倉 政 寛*，千葉隆 弘**，伊 東敏 幸***，苫米地 司**** \\ Masahiro TAKAKURA, Takahiro CHIBA, Toshiyuki ITO \\ and Tsukasa TOMABECHI
}

\begin{abstract}
In this study, we examined the reliability of a method for evaluating snow load on a pitched roof that takes into account the occurrence of snow sliding. Data on the properties of adfreezing resistance and frictional resistance, the main resistant forces that determine the occurrence of snow sliding, were summarized from various previous reports. Based on these data, indoor and outdoor experiments were performed. The following results were obtained. 1) The degree of frictional resistance depends on the size of the snow particles. Frictional resistance decreases from about the fifth day after snow has accumulated on the roof, when the snow particles are $1 \sim 2 \mathrm{~mm}$ in diameter (granular snow). 2) Changes in adfreezing resistance depend on changes in atmospheric temperature. There is no adfreezing resistance when the atmospheric temperature rises above the melting point of ice. Based on the data of these two resistant forces, we calculated the number of days required for snow sliding to occur. Changes in atmospheric temperature and the natural rate of snow granulation were used as indices in the calculation. By using our method of calculation, we were able to clarify the number of days required for snow sliding to occur on a building with a pitched roof, indicating that it is possible to design a building for which snow load can be controlled.
\end{abstract}

keywords: Pitched roof, Snow load, Snow sliding off, Snow quality

勾配屋根, 積雪荷重, 雪の滑落, 雪質

1.はじめに

多雪地域に建設される建築物は，降積雪現象がもたらす問題を 除いて計画することができない。特に大規模構造物の積雪荷重は 大きな外力となり，構造上の制約を受ける場合が多い。そのため， 既存建築物のいくつかでは, この荷重を屋根雪の滑落によって積 極的に制御する試みが行われている1.21。このような考え方を取 り入れる場合は，滑落が発生するまでに要する期間が重要となる。 積雪荷重の評価について日本建築学会建築物荷重指針（以下，荷 重指針）をみると，実験や調査に基づいた検討によって十分に信 頼性のある屋根雪処理が可能な場合，降雪から処理に至る期間内 の積雪量を用いて積雪荷重を求めることが可能となっている ${ }^{3)}$ 。

雪が滑落するまでに要する期間を検討する場合, 滑落の発生条 件を明らかにしておく必要がある。ここで，建築基準法施行令第 86 条第 4 項をみると, 屋根勾配が $30^{\circ}$ を越える場合, 積雪荷重を 低減して評価することが可能となっている。既往の観測例をみて も, 屋根勾配の増加に伴って滑落現象が頻繁に発生するため, 積 雪荷重が小さくなる4 ${ }^{4}$ )。このように屋根勾配は, 雪の滑落によ る積雪荷重の増減を簡便に評価できる指標の一つと言える。一方, 屋根勾配のみでは, 屋根驀材の種類や外気温の影響による滑落特 性の違いを考虑することが難しいと考える。屋根雪の滑落現象を 支配する諸抵抗力について既往の研究をみると, 凍着抵抗力や摩
擦抵抗力，雪の破壊抵抗力が滑落条件に大きな影響を及ぼす5)。 これらの抵抗力は, 屋根草材の種類等, 建物固有の特性に影響を 受ける一方，外気温や雪質等にも影響を受ける ${ }^{6}$ 。従って, 雪が 滑落するまでに要する期間を予測しようとする場合は，屋根勾配 のみでなく，滑落を妨げる抵抗力を指標として滑落条件を定義す る必要があると考える。

このようなことから本研究は, 屋根雪の滑落に及ぼす雪質の影 響について検討を行った前報のににき続き，勾配屋根に扔ける積 雪荷重の設定に関する基礎資料の提示を目的とする。はじめに， 雪の滑落を支配する抵抗力を既往の研究から整理した。整理して 得られた結果に基づいて，雪質の経日変化に関する実験・観測を 行った。これらのことから, 屋根雪の滑落条件を定義し, 降雪か ら滑落までに要する日数の算出法を提案する。

\section{2. 雪の滑落を支配する抵抗力}

滑落現象を利用して積雪荷重の制御を行う場合, この現象に至 るまでの屋根上積雪状況を予測することが重要となる。この予測 を行うためには，屋根雪の滑落条件を明らかにする必要がある。 ここで，滑落現象を支配する抵抗力について整理すると次のよう になる。滑落現象を支配する抵抗力は，連続的な屋根雪の破断を 阻止する破断抵抗力と, 屋根雪と屋根苟材との間に発生する界面

\footnotetext{
* 北海道工業大学大学院 大学院生 $\cdot$ 修士 (工学)

** 北海道工業大学大学院 大学院生

**** 北海道工業大学建築工学科 助教授・博士 (工学)

**** 北海道工業大学建築工学科 教授・工博
}

Graduate Student, Graduate School of Hokkaido Inst. of Tech., M. Eng. Graduate Student, Graduate School of Hokkaido Inst. of Tech. Assoc. Prof., Dept. of Architecture, Hokkaido Inst. of Tech., Dr. Eng. Prof., Dept. of Architecture, Hokkaido Inst. of Tech., Dr. Eng. 
抵抗力に大別できる。前者の破断抵抗力には積雪の引張およびせ ん断抵抗力があり, これらの抵抗力は屋根形状の工夫, 屋根面の 温度分布を均一にすること等で低減あるいは解除することが可能 である? ${ }^{28}$ 。後者の界面抵抗力には, 凍着および摩摖抵抗力があ る。この 2 つの抵抗力について增減特性を考察すると, 以下のよ うになる。

\section{1 凍着抵抗力の増減特性}

既往のモデル実験結果9.10.11をみると，屋根用塗装鋼板にお ける $-10^{\circ} \mathrm{C}$ の凍着抵抗力は, いずれの研究でも $200 \mathrm{~kg} / \mathrm{m}^{2}$ 以上とな る。例えば, 屋根勾配 $30^{\circ}$ の建築物で, このような凍着抵抗力が 作用すると；滑落に必要な屋根上積雪深は $1.3 \mathrm{~m}(\sin \theta \times$ 積雪 単位重量 $\div$ 凍着抵抗力 $=\sin 30^{\circ} \times 300 \mathrm{~kg} / \mathrm{m}^{3} \div 200 \mathrm{~kg} / \mathrm{m}^{2}$ ） 以上とな る。ここで, 氷の融点である $0{ }^{\circ} \mathrm{C}$ 付近の凍着抵抗力について既往 の研究 ${ }^{2.13}$ を整理すると図－1になる。図のように, 凍着抵抗 力は, $-2^{\circ} \mathrm{C}$ 前後の温度になると急減する傾向がみられ, $0{ }^{\circ} \mathrm{C}$ 以上 になると殆ど作用しない。このように, 凍着抵抗力には顕著な温 度依存性があり, 承の融点に近づくに伴って滅少する。従って, 屋根雪が滑落するまでに要する日数を評価する場合, 凍着抵抗力 が継続的に作用する日数, すなわち外気温がマイナス温度で推移 する日数が重要な指攃の一つになると考える。

\section{2 摩擦抵抗力の増減特性}

既往の研究をみると, 摩摖抵抗力は, 屋根㯰材の表面粗度が増 加するに伴って大きくなる(1)。一方, 雪質の違いによっても, 摩擦抵抗力は大きく変化する。ここで, 雪質および屋根㯰材の表

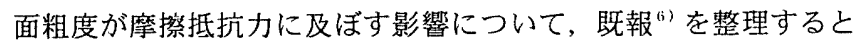
図一 2 になる。図のように, 屋根雪が滑動中の摩摖抵抗力である 動摩摖係数は, 屋根直材の表面粗度が大きくなると3〜5倍にまで 増加する。一方, 雪質が及ぼす摩摖への影響についてみると次の ようになる。屋根雪の雪質がしまり雪（粒径0. 1 0. $5 \mathrm{~mm} ）$ の場合 は, 屋根葷材と雪との界面で発生した水分が雪に吸い上げられる 現象 (毛管現象) が発生するため ${ }^{51}$ ，摩摖抵抗力が極めて大きく なる。この場合の動摩摖係数は平滑な塗装鋼板（ $\mathrm{Rz}=1.4 \mu \mathrm{m})$ で 0.75 , 粗面の場合 $(\mathrm{Rz}=23.16 \mu \mathrm{m})$ で2. 5程度となる。一方, ザラ 入雪 2 (粒径 $1 \sim 2 \mathrm{~mm}$ ) のように粗大化した雪粒子の場合, 動摩摖 係数は水分の影響を受けにくく, 平滑な塗装鋼板の場合で 0.25 , 粗面の塗装鋼板では1. 25前後となる。このように, ザラメ雪 2 に おける摩摖抵抗力は, しまり雪の場合に比べて約 1/2にまで減少 する。これらのことから, 摩擦抵抗力は雪粒子が大きくなるに伴 って減少し, 雪が滑落しやすくなると考える。

屋根雪の滑洛を支配する抵抗力をみると, 凍着抵抗力の増減は 外気温の推移に依存する。一方, 摩摖抵抗力は, 屋根㯰材の表面 粗度の影響を受ける一方で, 雪粒子のザラメ化にも支配されてい る。これらの結果をみると, 凍着・摩摖抵抗力の依存指惯を適切 に組み合わせることで, 屋根雪が滑洛するまでに要する日数が算 川できると考える。

\section{3. 積雪最下層における雪粒子の経日変化}

摩摖抵抗力は, 屋根雪の最下層におけるザラメ化の影響を受け
る。そのため, 粒径0. 1〜0.5mmのしまり雪では, 屋根雪が滑落し にくい。一方, 粒径 1 2mmのザラメ雪になると滑落しやすくなる。 従って, 滑落の発生に要する日数を評価する場合は, 最下層の雪 粒子がザラメ化するのに要する日数を明らかにしておく必要があ る。このことから, 屋根雪の最下層における雪粒子の経日変化に 関する屋内・屋外実験を行った。

\section{1 実験および観測の方法}

雪粒子の経日变化に関する屋内実験は, 図ー 3 に示す模擬屋根 (無暖房) を低温室内に設置して行った。図のように, 模擬屋根 には自然雪を $10 \mathrm{~cm}$ 堆積させて, 屋根莫材に接する最下層の雪粒子 を24時間経過毎に採取した。雪粒子は融解を防ぐため, 採取直後 に $-5^{\circ} \mathrm{C}$ の低温室内でビデオカメラ（倍率10倍）で搬影した。批影 は各時間毎に 3 回行い，15個の雪粒子から平均雪粒径を算出した。 なお, 低温室の室温は, 札幌における1〜2月の外気温平年值を想

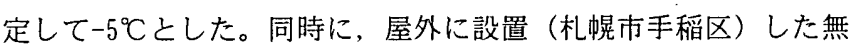
暖房の屋根 (滁装鋼板亘) を対象に, 雪粒子の経日変化を観测し た。なお，この観測は1999年 1〜2月に実施し，観測方法は屋内 実験と同様である。これらの屋内・屋外の実験結果から雪粒子の ザラメ化について評価した。

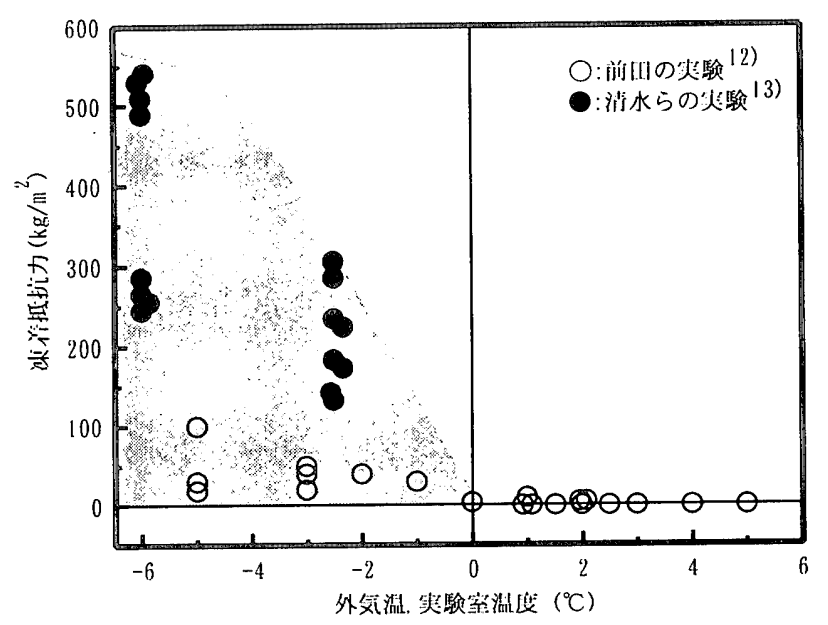

図一 1 既往の研究から得られる凍着抵抗力

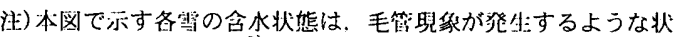
愁(

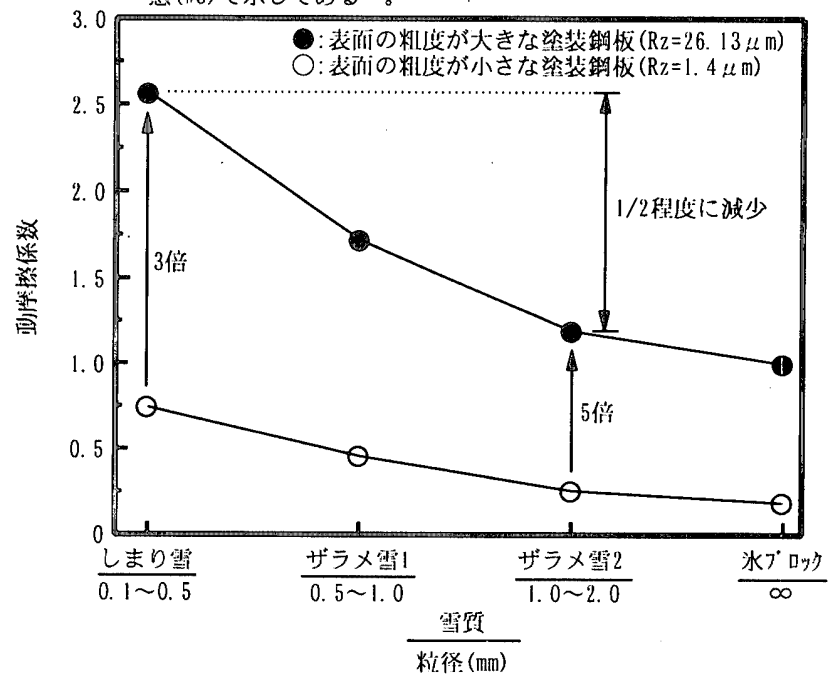

図一2 摩擦抵抗力に及ぼす雪質の影響 


\section{2 雪粒子の粗大化状況}

屋根雪の最下層における雪質を観察したところ，雪粒子は，写 真一 1 のように，日ごとに大きくなってゆく様子が確認できた。 このような雪粒子の経日変化をみると図一 4 になる。なお, 図中 には，建物内部で暖房（野地板温度 $2.4^{\circ} \mathrm{C}$ ）を行っている場合の 結果を併せて示してある ${ }^{16)}$ 。図のように，暖房を行っている場 合，最下層の雪は 2 日で $1 \mathrm{~mm}$ を越える粒径となる。一方，無暖房 の場合をみると， $1 \mathrm{~mm}$ 越える粒径となるのに 4〜 5 日を要して いる。なお，勾配屋根における屋根上積雪の調查を行った既往の 研究結果をみると, 無暖房屋根の場合, 最下層の雪が $1 \sim 3 \mathrm{~mm}$ の 粒径となるのに $3 \sim 4$ 日を要している")。

次に，雪粒子のザラメ化に及ぼす外気温の影響についてみると 平均気温が最も低い 1 月 28 日からの観測では， $1 \mathrm{~mm}$ 以上の粒径と なるのに要する日数が最も長くなっている。既往の研究をみると， $50 \mathrm{~cm}$ を下回る積雪深の場合，'雪の下層温度は，外気温の影響を受

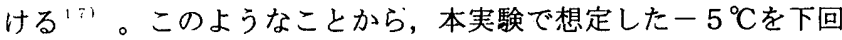
る外気温で, 積雪深が $50 \mathrm{~cm}$ 未満となる地域では, 図一 4 に示した 粒径粗大化に要する日数よりも大きな值を採る必要がある。

屋根雪の最下層が滑落しやすいザラメ雪. (粒径 $1 \sim 2 \mathrm{~mm}$ ) とな るためには，降雪から数日間程度の期間を要する。このように雪 粒子がザラメ化してゆく過程をみると，屋根雪の滑落に要する日 数を評価する場合，摩擦抵抗力へ及ぼすザラメ化の影響を考慮す る必要がある。また，滑落が発生するのに要する日数とその時の 雪質が明らかになれば，雪質と摩摖抵抗力の関保から屋根勾配を 設定することが可能になると考える。

\section{4. 凍着抵抗力が作用することを考盧した滑落の評価}

屋根雪の滑落現象は, 摩擦抵抗力のみでなく凍着抵抗力が及ぼ

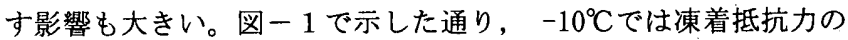
影響によって雪が滑落しにくい。一方，この抵抗力は $0{ }^{\circ} \mathrm{C}$ 以上に なると, 殆ど作用しない。このことから, 滑落現象の発生に要す る日数を評価する場合, 外気温がマイナス温度で推移する日数が 重要な指標の一つになると考える。このことから，外気温がマイ ナス温度で推移する日数を気象資料から算出した。

\section{1 凍着抵抗力が作用する条件}

凍着抵抗力は； $0{ }^{\circ} \mathrm{C}$ 以上になると殆ど作用せず，雪が滑落しや すくなる。このことから, 本研究では, 凍着抵抗力が作用するか 否かの境界を $0{ }^{\circ} \mathrm{C}$ と考えて, 日最高気温が $0{ }^{\circ} \mathrm{C}$ 以下で推移する期 間を凍着抵抗力の作用日数と定義した。ここで, 凍着抵抗力の作 用日数は，積雪荷重の評価に大きく関わるので，荷重指針に示さ れているような建築物の設計法に対応した資料を提示する必要が ある。このことから，凍着抵抗力の作用日数の各年極值を気象資 料から抽出し， 100 年再現期待值を算出した。再現期待値の算出 はGumbel確率紙に作用日数の極值 (33年分)をプロットし，プロッ. 卜值を直線回帰して求めた。なお，凍着抵抗力の作用日数の算出 に用いた気象資料は，荷重指針における再現期待値算出に用いら れている観測年数（平均34年間）. と同等の観測年数を持つ資料と して，全国の気象官署抢ける33年間 $(1962 \sim 1994$ 年)の気象観測值 が収録されている地上気象観測原簿データ ${ }^{181}$ とした。

\section{2 凍着抵抗力の作用日数の算出方法}

凍着抵抗力の作用日数の各年極值をGumbel確率紙上にプロット した結果を札幌・釧路を一例として示すと図一 5 になる。図のよ うに，凍着抵抗力の作用日数は必ずしも值線的な分布形状ではな く，地点ごとに極值分布（プロット值の分布）が異なっている。 そのため，33年間分のプロット值全てを直線回帰（破線）して 100年再現期待值を得ると, 釧路のように過小評価する場合があ る。ここで，地点によって極值分布の形状の違いが指摘されてい る年最大積雪深では，極值上位 $1 / 3$ のプロット值のみを直線回帰

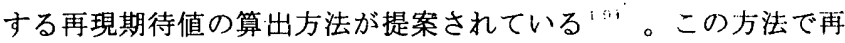
現期待値を算出すると，図一 5 中の実線で示した回帰式になる。

\section{低湿穿温这: $-5^{\circ} \mathrm{C}$}

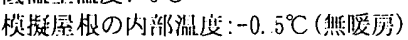

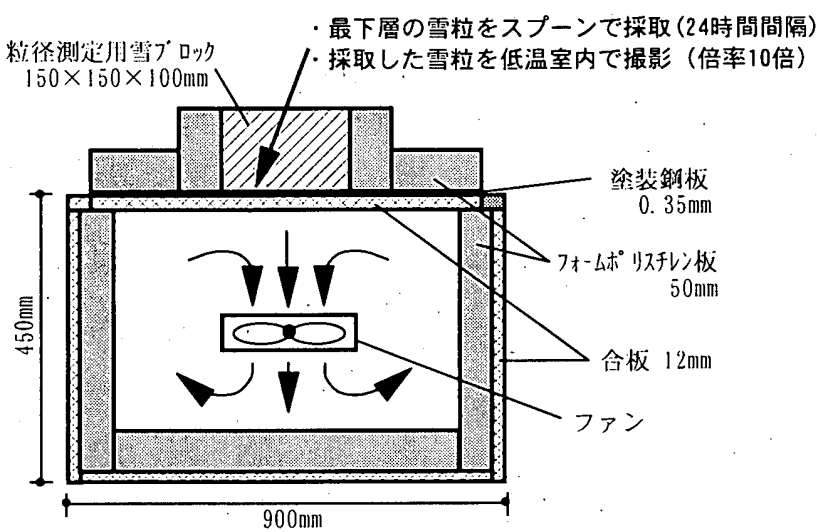

図ー3 屋内実験に用いた模擬屋根
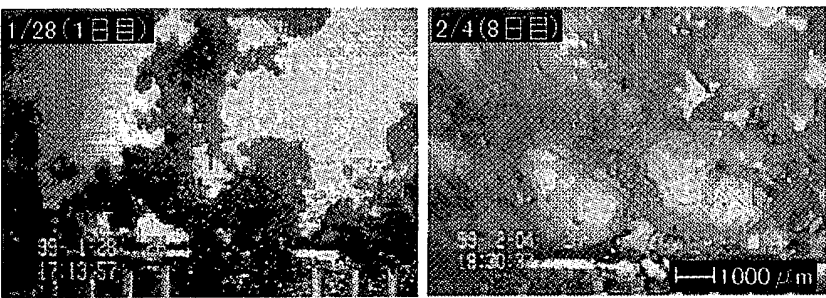

写真ー1 屋外観測によるザラメ化の様子(無暖房)

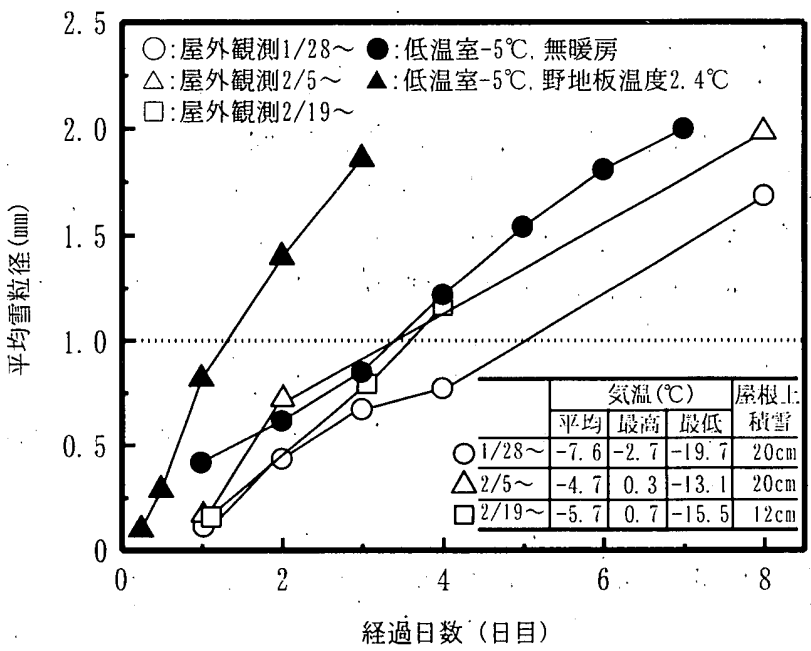

図-4 屋根上積雪の最下層における雪粒子の経日変化 
再現期間（年）

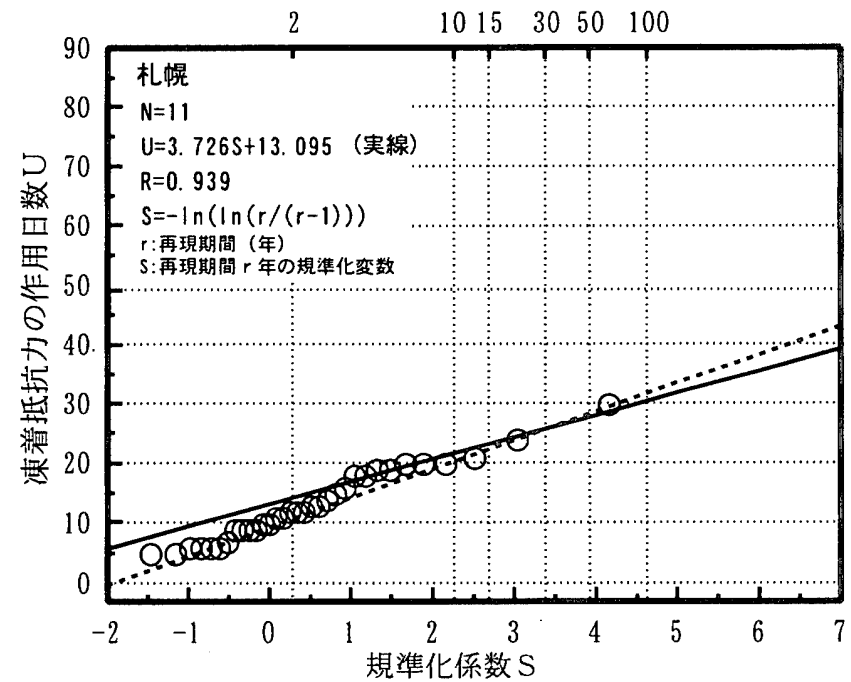

再現期間（年）

$1015 \quad 3050 \quad 100$

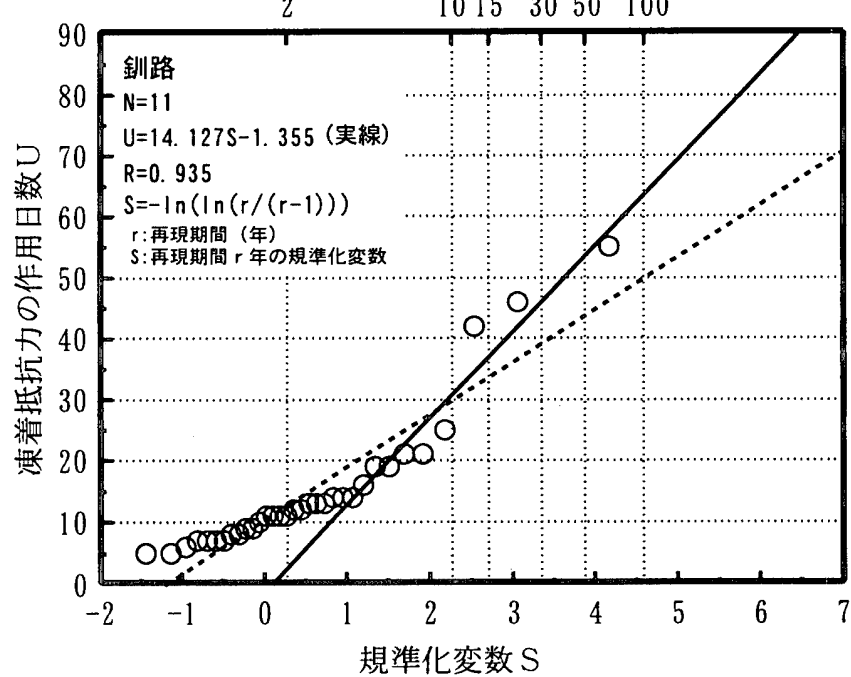

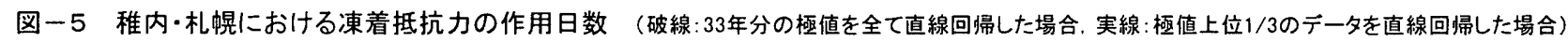
表-1 多雪地域における凍着抵抗力の作用日数

\begin{tabular}{|c|c|c|c|c|c|c|c|c|c|}
\hline 所在地 & $\begin{array}{l}\text { 気象官 } \\
\text { 署名 }\end{array}$ & 北緯 ( ${ }^{\circ}$ ) & 標高 (m) & $\begin{array}{l}\text { 凍着抵抗力の } \\
\text { 作用日数 (日) }\end{array}$ & 所在地 & $\begin{array}{l}\text { 岗象宫 } \\
\text { 署名 }\end{array}$ & 北緯 $\left(^{\circ}\right)$ & 標高(m) & $\begin{array}{l}\text { 凍着抵抗力の } \\
\text { 作用日数 (日) }\end{array}$ \\
\hline 百海道 & 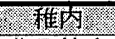 & 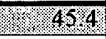 & 2.28 & 7. & 青森 & 八户 & 40.5 & 27.1 & 12 \\
\hline 北海道 & 北見枝幸 & 44.9 & 6.1 & 92 & 秋田 & 秋田 & 39.7 & 9.4 & 10 \\
\hline 北海道 & 羽幌 & 44.4 & 7.9 & 64 & 岩手 & 大船渡 & 39.1 & 36.5 & 10 \\
\hline 北海道 & 雄武 & 44.6 & 13.8 & 99 & 岩手 & 盛岡 & 39.7 & 155.2 & 14 \\
\hline 北海道 & 留萌 & 44.0 & 22.0 & 60 & 岩手 & 宮古 & 39.7 & 42.5 & 7 \\
\hline 北海道 & 旭川 & 43.8 & 111.9 & 81 & 山形 & 新庄 & 38.8 & 94.4 & 15 \\
\hline 北海道 & 網走 & 44.0 & 37.6 & 69 & 山形 & 酒田 & 38.9 & 3.1 & 9 \\
\hline 北海道 & 小樽 & 43.2 & 24.9 & 44 & 山形 & 山形 & 38.3 & 152.5 & 12 \\
\hline 北海道 & 札幌 & 43.1 & 17.2 & 31 & 新潟 & 相川 & 38.0 & 34.6 & 5 \\
\hline 北海道 & 岩見沢 & 43.2 & 42.3 & 61 & 新潟 & 新潟 & 37.9 & 1.9 & 7 \\
\hline 北海道 & 带広 & 42.9 & 38.6 & 48 & 新潟 & 高田 & 37.1 & 12.9 & 5 \\
\hline 北海道 & 釧路 & 43.0 & 31.7 & 63 & 宮城 & 仙台 & 38.3 & 38.9 & 7 \\
\hline 北海道 & 根室 & 43.3 & 25.8 & 58 & 宮城 & 石巻 & 38.4 & 43.0 & 9 \\
\hline 北海道 & 寿都 & 42.8 & 15.7 & 37 & 石川 & 輪島 & 37.4 & 5.3 & 4 \\
\hline 北海道 & 室闌 & 42.3 & 42.6 & 41 & 石川 & 金沢 & 36.6 & 26.1 & 4 \\
\hline 北海道 & 苫小牧 & 42.6 & 5.9 & 35 & 富山 & 伏木 & 36.8 & 12.1 & 4 \\
\hline 北海道 & 浦河 & 42.2 & 33.5 & 39 & 富山 & 富山 & 36.7 & 8.6 & 7 \\
\hline 北海道 & 江差 & 41.9 & 3.7 & 25 & 長野 & 長野 & 36.7 & 418.2 & 10 \\
\hline 北海道 & 函館 & 41.8 & 33.2 & 22 & 長野 & 松本 & 36.3 & 610.0 & 5 \\
\hline 北海道 & 俱知安 & 42.9 & 174.4 & 57 & 長野 & 諏訪 & 36.1 & 760.3 & 7 \\
\hline 北海道 & 紋別 & 44.4 & 15.8 & 74 & 福央 & 福井 & 36.1 & 9,1 & Fis \\
\hline 北海道 & 広尾 & 42.3 & 32.4 & 46 & 岐卓 & 高山 & 36.2 & 560.2 & 9 \\
\hline 青森 & 深浦 & 40.7 & 66.1 & 21 & 鳥取 & 境 & 35.6 & 2.1 & 3 \\
\hline 青森 & 青森 & 40.8 & 3.0 & 22 & 景都 & 舞鶴 & 35.5 & 2.5 & 2 \\
\hline 青森 & tpo & 41.3 & 2.9 & 26 & 滋賀 & 彦根 & 35.3 & 87.3 & 2 \\
\hline
\end{tabular}

この図から得られる再現期待值は, 再現期間 2 年(非超過確率50 \%）のようにその期間が極めて短い場合，再現期待值がブロット 值を下回る場合があるものの，再現期間100年 (非超過確率99\%) に対する值を得る場合，33年分全てを直線回帰した場合（破線） に比べてブロット值に近似した再現期待值を得ることができる。 凍着抵抗力の作用日数は，その值が積雪荷重の評価に用いられる 場合，非超過確率50\%のような平年的な数值が要求されるのでは なく, 而用年数中に起こり得る最大值が必要となる。このことか ら, 以下の検討では凍着抵抗力の作用日数として極值上位 $1 / 3$ の ブロット值のみを直線回帰して得られる100年再現期待值を用い ることにした。

\section{3 地点別にみた凍着抵抗力の作用日数}

全国の気像官署における凍着抵抗力の作用日数について 100 年 再現期待值を算川した。その一例として, 多雪地域に属する地点
での算州結果を表ー 1 に示す。表のように，緯度が高い地点にな ると涷着抵抗力の作用日数は長期間となる。また，緯度が $38.5^{\circ}$ 以上の場合，新庄と酒田のように同緯度の地点でも，临高の高い 新庄の作用日数は，酒田に比べて大きな值となる傾向がみられた。 ここで, 稚内における算出結果をみると, 凍着抵抗力の作用日数 は75日となり，2.5ケ月の間，滑落が発生しにくい状況が継続す ることになる。すなわち，凍着抵抗力の增減特性からみると，滑 落の処理日数として75日を設定する必要がある。一方，祝井の算 似結果をみると, 凍着抵抗力の作用日数は，4日となる。この結 果に従って, 凍着抵抗力の増減のみを指祭とする場合, 福井では, 滑落の処理日数は 4 日とすることが可能になる。

\section{5. 積雪荷重の制御に要する日数に関する考察}

凍着抵抗力の作用日数を算川したところ, 袻井での作用日数は 4 日となった。しかし，摩擦抵抗力の影響を考慮すれば，屋根雪 

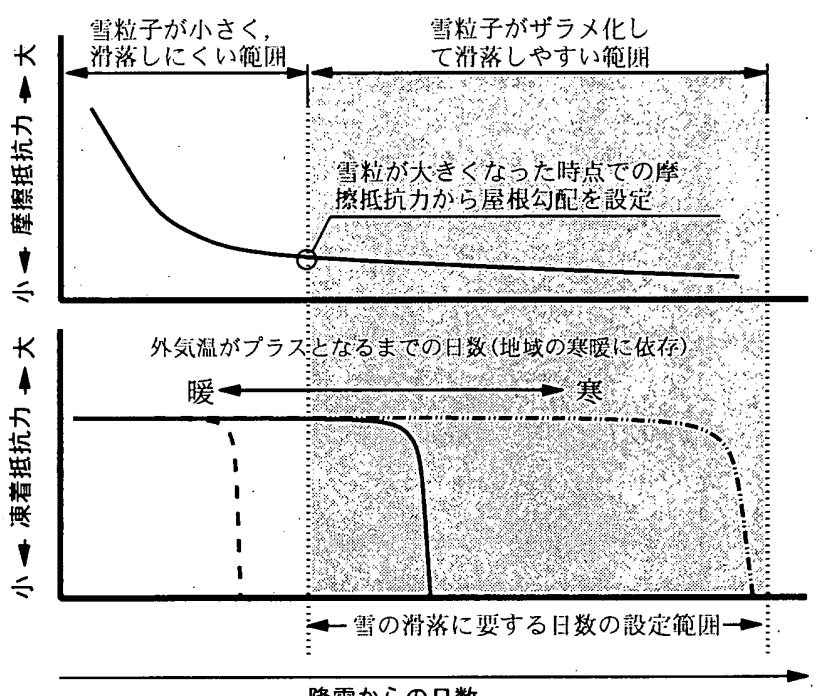

降雪からの日数

- - - :プラスの外気温になることが多い地域 (A)

-...... : :イナスの外気温になることが多い地域 (B)

—AとBの中间地域

図一6 日数を基軸とした場合における凍着·摩擦抵抗力の推移

のザラメ化が 4 日以内に起こらない場合，滑落が極めて発生しに くいこととなる。すなわち, 屋根雪の滑落に要する日数は, 凍着 抵抗力の増隇のみを指䌘とした場合，危険側に評価するケースも あり得る。このことから, 凍着抵抗力のみでなく, 摩摖抵抗力の 増減特性を組み合わせて, 雪が滑落するまでに要する日数の評価 手法について考察する。凍着・摩摖抵抗力の增减特性を雪の滑落 に必要な日数として整理すると図ー6になる。はじめに，凍着抵 抗力について考察すると, ブラスの外気温となることが多い地域 の場合，この抵抗力は短期間のうちに小さな值となる。しかし， 摩摖抵抗力をみると, 降雪直後は雪粒子が小さいことから，滑落 しにくい。このことから，凍着抵抗力の作用日数が雪粒子の粗大 化に要する日数よりも短い場合は，摩摖抵抗力の增減特性を基蕉 とした滑落の評価を行う必要がある。具体的には，図ー4に示し た札幌における雪粒子の粗大化に要する日数を基倠とした場合, 荷重評価に用いる積雪深は，5日を上回る増分積雪深とする必要 がある。また，多雪地域で一般的に用いら扎いる塗装鋼板は， 経年劣化に伴って表面粗さRzが増加し，25年以上経過するとRzが $17 \sim 26 \mu \mathrm{m}$ 程度になる ${ }^{20)}$ 。図 - - 2 の通り，摩擦抵抗力は，屋根莫 材の表面粗度の増加に伴って3〜5倍になる。すなわち, 屋根莫材 が劣化するほど，滑落は見込めなくなることも十分に考慮する必 要がある。

これらのことから, 屋根雪の滑落処理に要する日数は, 人工的 に屋根面に熱を与える融滑雪処理”1! を使用しない自然滑落の場 合，屋根雪のザラメ化による摩摖抵抗力の増減を考慮した日数を 設定する必要がある。なお，荷重指針では，制御積雪荷重を算比 する際の積雪深として，7 日增分積雪深を提示している。この 7 日增分積雪深は, 凍着抵抗力の作用日数および屋根雪のザラメ化 に要する日数が 7 日以下の地域に建設される勾配屋根の有效な荷 重評価指呩になると考える。一方，マイナス温度が長期間継続す るような北海道等で自然滑落を考える場合は，凍着抵抗力が 7 日 以上継続的に作用する。このような地点では，凍着抵抗力の作用
する日数内における積雪深（例えば，稚内では75日間の積雪深） を算比することで，勾配屋根で発生する滑落を考虑した制御積雪 荷重を算出することが可能になると考える。

\section{6. まとめ}

本研究では，勾配屋根における雪の滑落を考慮した屋根上積雪 荷重の評価手法について検討した。はじめに, 滑落現象の発生を 支配する抵抗力として, 凍着抵抗力および摩摖抵抗力の特性につ いて既往の研究を整理した。整理して得られた結果から，摩摖抵 抗力の雪質依存性, および凍着抵抗力の温度依存性について検討 した。これらのことから, 雪質のザラメ化に要する日数, および 外気温がブラス温度となる日数を基軸とした滑落の発生に要する 日数の算出法を提案した。屋根雪の滑落に要する日数が明らかに なることで, 公配屋根を持つ建築物における積雪荷重評価の際に 制御積雪荷重を用いることが可能であることを示した。

\section{【参考文献】}

1) 小竹達也, 他 4 名: 積雪地域に建設される膜構造物における 屋根上積雪荷重の評価について，日本建築学会技術報告集， 第 3 号, pp. 34-39, 1996. 10

2）倉橋勲，他 4 名：（仮称）但馬ドームの積雪荷重の検討，日 本建築学会技術報告集，第 5 号，pp. 91-95，1997. 12

3) 日本建築学会編：建築物荷重指針・同解説，第5章 積雪荷重, pp. $168-235,1993$

4) 木村幸一郎：屋根上積雪の自然落下について, 日本雪氷学会 誌, 第 5 巻 7 号, pp. 6-9, 1943.7

5) 清原潔 : 住宅屋上積雪の建築計画的取り扱い方法に関する研 究, 北海道寒地建築研究所研究報告, No. 5, 1960.2

6)高倉政寛，伊東敏幸，苫米地司：経時的に雪質の变化した屋 根上積雪と塗装鋼板との摩摖特性, 日本建築学会構造系論文 集，第510号，pp. 45-50，1998.8

7)島田洋: サスペンション膜構造物の除雪実験, 日本雪工学会 誌, Vol. 6, No. 3, pp. 10-17, 1990.9

8）苫米地司，他 3 名：屋根雪の滑雪現象に関する基礎的研究, 日本雪工学会誌, Vol. 11, Nó. 2, pp. 2-9, 1995.4

9) 渡辺正朋 : 屋根莫材と雪水との凍着強さに関する研究, 第 9 回日本雪工学大会論文報告集, pp. 127-130，1993.1

10) 吉田光則, 他 7 名 : 着水雪防止技術に関する研究, 各種材料 の着氷力について，北海道の雪永，第12号，pp. 24-26，1993

11）苫米地司，伊東敏幸：屋根上積雪荷重の制御に関する基礎的 研究，日本雪水学会誌，第56巻 3 号, pp. 215-222，1994.9

12) 前田博司：金属板屋根における積雪の滑落，日本雪水学会誌， 第 41 巻 3 号, pp. 199-204, 1979. 9

13) 清水増治郎, 木村忠志: 水点下における雪の屋根材への付着, 日本雪水学会誌，第 54 巻 3 号, pp. 269-275, 1992.9

14) 渡辺正朋，平井利喜：屋根蒙材と屋根雪の摩摖に関する研究, (その 2) 屋根莫材に対する雪氷の滑走速度および動摩摖, 日本雪工学会誌，第 9 号，pp. 4-15, 1988.12

15) 水野悠紀子, 若浜五郎：湿雪の付着強度, 低温科学, 物理編, 第35輯, pp. 133-145, 1977

16）伊東敏幸，高倉政寞，苫米地司：屋根雪の経時的な雪質変化 および摩摖特性，日本雪工学会誌，Vol. 15, No. 1, pp. 3-9, 1999. 1

17) 小島賢治：雪と氷 10 問 8 答，日本雪水学会誌，第 48 巻 3 号, pp. 159-167, 1986. 9

18)気象庁編：地上気象観測原簿データ（CD-ROM），気象業務支 援センター

19) 利泉正哲, 三橋博三, 高橋徹 : 年最大積雪深の確率統計的性 質之再現期間推定法，日本建築学会構造系論文集，第390号， pp. $49-58,1988.8$

20）伊東敏幸，苫米地司，星野政幸：劣化した塗装鋼鍍の表面性 状と滑雪性について，日本雪工学会誌，Vol. 10，№.2，pp. 2 $-10,1994.4$

21) 大塚清敏, 他 5 名 : 膜構造物の融雪・滑雪に関する研究, 膜 構造研究論文集” 91，№. 5，pp. 93-104，1991.12

（1999年 5 月 10 日原稿受理， 1999年 8 月 27 日採用決定） 